\title{
A Multiple Streams Approach to Understanding Social Policy in Ghana: The Case of Livelihood
}

\section{Empowerment against Poverty}

\author{
Saaka Sulemana \\ Department of Political Science, Brock University \\ 500 Glenridge Avenue, St. Catharines, L2S 3A1 \\ Ontario, Canada \\ E-mail: ss15of@brocku.ca
}

Received: Sep. 25, 2017 Accepted: Nov. 20, 2017 Online published: Nov. 26, 2017

doi:10.5296/jpag.v7i4.11903ＵRL: https://doi.org/10.5296/jpag.v7i4.11903

\begin{abstract}
This paper utilizes Kingdon's Multiple Streams Approach (MSA) to explain how Livelihood Empowerment against Poverty (LEAP) was created in Ghana. MSA explains that policies are made by governments under the conditions of ambiguity (Zahariadis, 2014). Therefore, the paper explores social policy in two different time periods, 1992 to 2000, and 2001 to 2008 and argues that, prior to 2001 social policy was relatively ineffective. However, this changed when the New Patriotic Party took office in 2001. By applying MSA, this paper makes a distinct theoretical contribution to social policy research in Ghana, and argues that the policy entrepreneurial role of Former President Kufuor undergirds the implementation of LEAP in 2008 .
\end{abstract}

Keywords: multiple streams approach, livelihood empowerment against poverty, social policy.

\section{Introduction}

In the development of social policy in Ghana, three main events are significant for consideration. The first is the official visit of Former President Kufuor to Brazil to discuss bilateral relationship with Former President Lulla, and during his visit, he had the opportunity to discuss Bolsa Familia. The second event was the ministerial reshuffling that saw Hon. Frema Osei-Opare designated as Deputy Minister for Ministry of Manpower Youth and Employment. The other important event is the decision of the planning and bureaucrats of the National Development Planning Commission to develop a social intervention policy. By 
utilizing Kingdon's Multiple Streams Approach, this paper explains the conditions that led to the development of the Livelihood Empowerment against Poverty (LEAP) policy in Ghana. There is good evidence that LEAP was implemented because of the crucial role played by three different institutional authorities by cooperating and sharing ideas that translated into the development of the policy.

Since the late 1990s, conditional cash transfer (CCT) programs have become an integral part of social protection in Latin American countries, and are fast becoming a common feature of social-protection programs across the developing world (Rabinovich \& Diepeveen, 2015, p. 637). Generally, most scholars who have studied social protection policy in developing countries have mainly concentrated on assessing the extent to which such policies have ameliorated the deplorable living standards of beneficiaries. As a result, the processes through which social policies are created are largely under-studied. The objective of this paper is to explain the process through which LEAP was created and implemented. The paper is organized as follows; the first section briefly outlines the methodology. The second section surveys the literature on the development of social policies in developing countries. The paper further lays the theoretical framework by discussing Kingdon's Multiple Streams Approach (MSA). In the fourth section, the essay explores Ghana's social protection policies under two different governments in two time periods, from 1992 to2000, and between 2001 and 2008. The paper then concludes with a discussion of the findings and their implications for the field of social policy in global south countries.

\section{Methodology}

This research is chiefly qualitative, and makes use of a diachronic case study research design. A diachronic case study is a cross-time comparison within a single case where significant changes between two time periods is measured (Gerring, 2004). In the history of Ghana's social policy, and for that matter the discussion of LEAP, two time periods are relevant: the periods between 1992 and 2000, and 2001 and 2008. The two timeframes are important for two reasons. The first is that, since the inception of Ghana's Fourth Republic in 1992, power has alternated between two ideologically opposed but dominant political parties. Secondly, both parties while in government deviated from proposed paths of pursuing social policy as captured in their political party campaign manifestoes. For instance, it is interesting to know that the National Democratic Congress (NDC), a social democratic party, failed to implement any social protection policy while in government between 1992 and 2000. On the other hand, the New Patriotic Party (NPP), a liberal democratic party, rigorously pursued social policies, including the National Health Insurance Scheme (NHIS) and the Livelihood Empowerment against Poverty (LEAP).

The paper generally depends on both academic journal articles and non-academic sources including data from government archives, and newspaper articles. The most anticipated problem for this paper is that there is insufficient literature on social policy in Ghana-LEAP. However, the paper relies on similar scholarly studies conducted in other developing countries. The justification is that Ghana, as a developing country, shares similar political and socio-economic characteristics with these countries. 


\section{Literature Review}

In reviewing the literature, the paper focused on a few selected cases to provide useful evidence on how social protection policies were designed in some developing countries. To begin with, Brazil implemented the Bolsa Familia to provide financial support to the segment of its population that is considered poor. Barrientos (2013) argued that the 1998 constitution is the most fundamental basis for Brazil's social policy. In furtherance of this argument, Barreintos (2013) posited that, even though there were no immediate policy interventions when the country democratized, there was a renewed commitment to address the huge social debt created by several years of dictatorial rule. Consequently, some municipalities began to introduce cash transfer systems. In fact, Bolsa Escola started as a municipal experiment and later spread to other municipalities across Brazil between 1997 and 2001(Barrientos, 2013). In addition, Hall (2006) noted that, due to the progress made in Bolsa Escola, Lula's government was regularly criticized by policymakers, experts, and beneficiaries. The towering pressure from the public necessitated the development of a national social protection policy. Around the same time, the World Bank recommended that it was necessary for the Government of Brazil to develop a policy that will reduce the level of poverty, and as so World Bank offered to provide technical and financial support for the policy (Callister, 2013). A third reason that accounted for the implementation of Bolsa Familia is that, the public became critical of the administrative inaccuracies and uncoordinated implementation of four existing programs that led to the duplication of a few beneficiaries to the detriment of many others (Skovdal et al., 2013; Soares, 2012). In short, Bolsa Familia was designed in 2003 because of a combination of two compelling factors: pressure from experts, policymakers, and the public to create a national social policy, and technical and financial support from the World Bank (Hall, 2006; Callister, 2013).

In a similar account, the Government of Argentina, in 2009, implemented a social policy called Argentina's Universal Child Allowance (AUH) aimed at increasing the enrolment of children in school. The AUH was developed by a presidential decree due to President Cristina Fernandez de Kirchner's commitment to create a policy that will support poor families to send their children to school (Rabinovich \& Diepeveen, 2015; Stephen, 2002). By considering some African countries, it is estimated that $46 \%$ of Kenya's population of 38 million people live below the poverty line. Consequently, there was wide public agitation and pressure from civil society organizations on the government to address the problem. The Kenyan government, fearing continuous public backlash, decided to create the National Social Protection Policy (NSPP) by an Act of Parliament (Ikiara, 2009; Republic of Kenya National Social Protection Policy, 2009). Similarly, Zambia implemented its Kalomo Pilot Social Cash Transfer Scheme (KPSCTS). According to Schubert (2005), KPSCTS was designed as a major response to the prevalence of poverty, precipitated by agitations from public advocacy groups. For example, Zambia National Farmers Union and Chamber of Commerce resorted to media coverage to garner public support which forced the government to consider their petition to implement a welfare policy. In the petition, the pressure groups urged the government to adopt the research project that was developed and successfully tested by German Technical Assistance (Schubert, 2005). In response, a committee was 
constituted to study the project and recommendations were made to the government and the project was adopted and reconstructed into a national policy (Ikiara, 2009).

In the literature of Livelihood Empowerment against Poverty in Ghana, Debrah (2013) argued that cash transfer became the mantra for poverty reduction in developing countries following a relative success in fighting poverty in Brazil. As a result, in March 2008 LEAP was officially launched by the erstwhile Kufour administration. Generally, the origin of LEAP can traced to three state authorities; (1) President Kufuor was encouraged by the successful implementation of the National Health Insurance Scheme (NHIS) and as a result, he instructed the Ministry of Manpower, Youth and Employment to create a social policy, (2)the planning bureaucrats of the NDPC claimed to have originated the idea of LEAP, and (3) Hon. Frema Osei-Opare argued that she was the brain behind LEAP (Grebe, 2014; Amazu, Jones, $\&$ Pereznieti, 2010). Interestingly, all these sources worked in tandem in the process that led to the development of the LEAP policy. Overall, studies conducted on LEAP mainly focused on assessing its effectiveness since its implementation (Bawelle, 2016; Handa S. et al., 2014; Roelen, Chettri, \& Delap, 2015). A gap in the literature is that there is no evidence or comprehensive and theoretical explanations underlining why LEAP was created. Therefore, this paper aims to contribute to social policy discussion by using Kingdon's Multiple Streams Approach to explain how the Livelihood Empowerment against Poverty was developed in Ghana.

\section{Description of Theory and Its Underlying Assumptions}

The Multiple Streams Approach is a theory that explains that policies are made by government under conditions of ambiguity (Zahariadis, 2014). Ambiguity in this context means that the state has potential options around an issue (Zahariadis, 2014). The theory has three major but separate and independent streams that flow through the policy process: the problem stream, the policy stream, and the politics stream (Zahariadis, 2014).The problem stream is where policy issues or problems are identified by individuals, groups, and institutions that the government should address, and Zahariadis (2014) noted that these individuals can be inside or outside the policy system. In explaining the problem stream, Kingdon (1995) identified three mechanisms-indicators, feedback, and focusing events- that are key for explaining the problem stream. According to Zahariadis "indicators may be used to assess the existence and magnitude of a problem and the scope of change" (2014, p. 32). Often times, research is conducted to measure these indicators. For example, illiteracy rate, income levels, population growth rate, maternal mortality, and crime rates are indicators. These indicators sometimes influence the direction of policy. While focusing events direct the attention of policymakers or government to certain questionable conditions, feedback from previous policies and programs essentially serve as a guide for determining solutions that will produce the intended results and those that may not work. Focusing events may be deliberate and coordinated actions, such as strike actions by organized labour groups, demonstrations and protests, or they may be unfortunate and devastating events such as accidents, terrorist attacks, or natural disasters.

The policy stream includes a "policy primeval soup" of ideas that compete to win acceptance 
in the policy networks (Zahariadis, 2014, p. 33). Members of policy communities, specialists in a given policy area, generate alternatives and proposals related to the issue-area; some ideas survive and prosper, others do not (Kingdon, 1995, p. 117). In other words, the policy stream is where experts or analysts suggest solutions to a particular problem.

Thirdly, the politics stream is made up of factors that influence the body politic, such as swings in national mood, executive or legislative turnover, and interest group advocacy campaigns (Kusi-Ampofo et. al., 2015; Zahariadis, 2014). The national mood of a country is determined when a sizeable portion of a country's population shares the same set of convictions on a particular issue and, depending on the circumstances of the issue, this mood changes from time to time (Kusi-Ampofo et. al., 2015, p. 202). Legislative turnover affects policy choices in many profound ways and come in many forms. Also, the role of interest groups in influencing policy choices is relevant to the politics stream. Zaharidis posited that "politicians often view the support or opposition of interest groups as indictors of consensus or dissent in the broader political arena" (2014, p. 34).

Three key assumptions guide the application of Kingdon's Multiple Streams Approach. The first assumption is that individual attention or processing is serial and systemic attention or processing is parallel. This suggests that individuals can only attend to one issue at a time due to their biological and cognitive limitations (Zahariadis, 2014). Consequently, policymakers are able to consider only a few policy issues at a time, thereby putting a limitation of the number of issues that a policy entrepreneur can push onto government's agenda. The other part of this assumption is that because governments are not bound by cognitive limitations and also because of the practice of division of labor, many issues receive attention concurrently. The second assumption is that policymakers operate under significant time constraints (Zahariadis, 2014). Policymakers do not have enough time on their hands when making decisions, thereby limiting the number of policy options available for consideration. However, this, in Zahariadis' view, does not imply that all decisions are crises. Thirdly, the streams flowing through the system are independent; each stream has a life of its own and does not depend on the other (Zahariadis, 2014).

Two other concepts that are relevant to the framework are policy windows and policy entrepreneurs. Policy windows are defined as fleeting "opportunities for advocates of proposals to push their pet solutions or to push attention to their special problems" (Kingdon, 1995 , p. 165). There are two ways that a policy window opens; either by the emergence of a serious problem or by events in the politics stream. Policy windows are opened by enthralling events mostly caused in the politics stream, and last for a very short period of time within which the opportunity is either taken and actions are initiated or it is lost. On the other hand, Policy entrepreneurs are individuals or corporate actors who attempt to couple the three streams (Zahariadis, 2014, p. 35). They are also described as power brokers or coalition enablers among other things. Generally, policy entrepreneurs exploit policy windows by pushing through proposed solutions or seek attention for some specific problems.

\section{Social Policy under the NDC Government between 1992 and 2000}

Ghana transitioned into a democracy in 1992 after struggling with a series of military 
interventions that interrupted civilian governments between 1966 and 1991. In 1992, Ghana held both presidential and parliamentary elections. Former President Rawlings, who had initially resisted multi-party politics, was elected a democratic president and his National Democratic Congress (NDC) won an overwhelming parliamentary majority (Adedeji, 2001, p. 2). Even though achieving a landmark in democratic governance signalled a promising future for the country, there were several challenges that the NDC government needed to aggressively address.

\subsection{The Problem Stream}

There were growing concerns in the early 1990s of the sluggish growth in real GDP and per capita incomes, the deterioration in trade balance and the overall balance of payments situation (Debrah, 2009; Ibrahim \& Yeboah, 2013; Oduro, 2015). The rate of growth of real GDP and Gross National Product (GNP) dropped from 5.0\% in 1991 to 3.5\% in 1992 (Debrah, 2009, p 93). Trade balance continued its downward spiral with imports soaring over exports and, as a result, Ghana's current account balance deteriorated sharply (ISSER, 1993, p. 10). Employment in the private sector decreased by $40 \%$ between 1985 and 1990while in the public sector the decrease was about 52\% (ISSER, 1993). Poverty headcount indices showed that $31.4 \%$ of the population was poor in 1992 (World Bank, 1995). It is evident that a probable combination of these factors exacerbated the prevalence of poverty in Ghana in the 1990s. Given the socio-economic status of the country, the NDC government faced a monumental task of implementing policies that would adequately address most of these problems. During this period, pressure from interest groups was not enough to influence the decisions of government. Also, pressure and criticism from the main opposition party, New Patriotic Party (NPP) on government's lack of commitment towards addressing poverty failed to attract any sympathies from the public because the party boycotted the 1992 parliamentary elections, and this was considered a threat to the renewed interest in democratic governance.

\subsection{The Politics Stream}

There was a major problem in the politics stream between 1992 and 2000. The politics stream in this period was less active as compared to the period between 2001 and 2008. One explanatory factor is that the national mood and the political atmosphere in Ghana at that time was characterized by what is mostly described as a "culture of silence" in which people were afraid and quietly refrained from making critical ulterances about the military government. This was because anyone who criticized the government during the Provisional National Defense Council (PNDC) regime was literally begging for a prison sentence, if not worse. In this regard, even though there was a problem-high prevalence of poverty-academics, interest groups and think tanks among others were scared to call on the government to take necessary measures. It is also important to add that there was no legislative turnover because the NDC/PNDC government had governed the country for the previous 21 years. Again, members of parliament, by virtue of how the constitution structured political power, played second-fiddle to the executive president. Finally, by 1996, the economy had recorded marginal improvements and poverty levels had seen some reduction (Debrah 2009, p.100). To some extent, this slight improvement in the economy lifted the 
national mood and may have diverted public attention away from the issue of poverty.

\subsection{The Policy Stream}

Around the late 1990s, it became obvious that poverty was a major socio-economic problem yet the political commitment to effect policy change was lacking (Dako-Gyeke \& Oduro, 2013; Abebrese, 2011). This was partly because the government was implementing IMF and World Bank's Structural Adjustment Program (SAP). As one of the conditions for the adoption of SAP, the government was required to to drastically cut down on its public spending and privatize most of the key state owned enterprises (Abebrese, 2011; Osei, 2011; PRS, 2004). As a result of SAP, any policy that could increase public spending was not on the agenda of government. The NDC government was constrained by the austerity measures prescribed by the Bretton Woods institutions during the implementation of SAP. The austerity measures were oriented around macroeconomic stability with an emphasis on prudent fiscal, monetary and international trade management (Debrah, 2013; Dako-Gyeke \& Oduro, 2013). Any solutions or ideas generated outside SAP did not receive government's attention because such ideas needed the approval of IMF and World Bank. Even though the problem of poverty existed and needed to be addressed, the avenues for actors to propose solutions were narrowly restricted. It also follows that, there were no activities of policy entrepreneurs through which the three streams could be coupled and, as a result, there was no policy window for policy entrepreneurs to actively exploit and push forward their policy alternatives.

\section{Social Protection Policy under the NPP Government between 2001 and 2008}

There was a change in government in 2001 after the New Patriotic Party (NPP) won the general elections in December 2000. This alternation in power implied a perceived change in the direction of social policy and many academics and policy analysts monitored the activities of the new government with keen interest. However, by early 2000s, there was growing concern about the threat that poverty posed to women, children, elderly, and vulnerable people across the Global South (Lloyd-Sherlock, 2000; Barrientos \& Lloyd-Sherlock, 2002; Barrientos, Gorman, \& Heslop, 2003). In order to correct public perception that the NPP government is a market-oriented government, and also to remain popular among the people, the government acted swiftly by implementing the National Health Insurance Scheme (NHIS) in 2003. At this point, the general attitude of Ghanaians was imbued with optimism and confidence that the government would implement several other policies that would ameliorate the impoverished living status of many its citizens.

\subsection{The Problem Stream}

As noted earlier, the problem stream broadly defines problems or policy issues that both policy makers and citizens want to be addressed. Several factors emerged that defined poverty as a problem which required certain policy responses from the government. These include; unemployment, inflation, unfavorable balance of payment, and malnutrition (Bawelle, 2016; Abebrese, 2011). In 2001, the economy inherited by the NPP government was characterized by huge fiscal deficits and a heavy debt burden. Although poverty was a 
major issue on the agenda, the government's desire to implement the National Health Insurance policy placed limitations on the capacity of the new government to immediately address the high incidence of poverty (Debrah, 2013). There were other competing problems such as high rate of unemployment, erratic power supply, and high rate of inflation.

In the discussions that led to the development of LEAP in 2008, a number of studies or surveys were conducted to assess and measure the rate of poverty in Ghana. First, Poverty Reduction Strategy (PRS) conducted a nationwide survey in 2004 and the findings of the survey showed that $35 \%$ of the population was in poverty (PRS, 2004). Moreover, Ghana Living Standard Survey (GLSS) periodically conducts and publishes reports on the living conditions of Ghanaian households, and in its 2005/2006 report (GLSS-5), it indicated that $28.5 \%$ of Ghanaians were poor and about $18.2 \%$ were languishing in extreme poverty, describing them as those whose standard of living is insufficient to meet their basic nutritional requirements even if they devoted their entire consumption budget to food (GLSS, 2006, p. 11). There were other complementary studies including; the National Development Planning Commission(NDPC) commissioned Poverty Social Impact Assessment Study and United Nations Common Country Assessment on Vulnerability and Exclusion in 2004, and reports on social intervention activities of international organizations such as the World Food Programme (WFP), Action Aid, CARE International, World Vision Ghana, Catholic Relief Services (CRS), PLAN Ghana, the World Bank, UNICEF which informed the formulation of the strategy (Ministry of Manpower Youth and Employment, 2007, 32). The statistical reports on poverty were mainly picked up and run on the front pages of credible newspapers including Ghanaian Times, Daily Graphic, and Daily Guide. Sections of the population blamed the liberal polices of the government for the high rate of poverty while others attributed it to previous austerity policies such as SAP. Kingdon argued that problem identification contains a "perceptible interpretive element" (1995, p. 110) and, in this sense, the values and beliefs of people constitute how problems are conceived as policy issues. The government at this point was being cautious and attentive to this problem because of its potential ramifications on the electoral fortunes of the party going into the 2008 general elections. Consequently, steps were taken to design a policy that would abate the prevalence of poverty and increase the government's popularity.

\subsection{The Policy Stream}

In the policy stream, a variety of ideas are generated and solutions are proposed for dealing with an identified problem. Different policy "brokers like bureaucrats, congressional staff, interest groups, policy analysts and other stakeholders may provide inputs for a solution" (Kusi-Ampofo et al., 2015, p. 202). Adding to the above, academics, think tank groups, stakeholders including intergovernmental organizations such as IMF and World Bank also make policy recommendations to government. The NPP government's term of office coincided with a strong transnational 'poverty reduction agenda' in the engagement of international agencies (most prominently the World Bank and International Monetary Fund) with Sub-Saharan African countries (Grebe, 2014). Consequently, donors such as the Department for International Development (DFID) were increasingly frustrated with the failure of development interventions and were starting to promote social protection in general 
(Grebe, 2014). The policy reform process in Ghana should therefore be viewed in the context of a strong transnational agenda, partially backed by the force of "conditionalities" imposed under the HIPC programme, and strongly promoted by certain donors (Grebe, 2014, p. 10).

Characteristically, policies are always proposed and formulated by government ministries and agencies in Ghana and, because LEAP was a pro-poor policy initiative and a model of the most touted Bolsa Familia implemented in Brazil, there were very few viable competing alternatives. By extension, Grebe (2014) argues that LEAP was ultimately considered as the best alternative in a stakeholder committee that was assembled, chaired by the Deputy Minister for Social Development (Hon. Frema Osei-Opare). Representatives of the Ministries of Health, Agriculture, Women and Children's Affairs, Education, the Ministry of Finance, the NDPC and a few Non-Governmental Organizations (NGOs) were actively involved in the process. In terms of technical feasibility, broader consultations were made during the design of LEAP including think tanks, interest groups, academics, and more importantly consultants from Brazil, South Africa, and Tunisia.

\subsection{The Politics Stream}

An administrative or cabinet reshuffle in the second term of President Kufuor designated Hon. Osei-Opare as the Deputy Minister of Manpower Youth and Employment (MMYE) and she brought with her a wealth of experience working with social welfare-oriented NGOs. This complete legislative turnover made the process of developing LEAP easier for the government even though concerns were raised by the minority caucus over government's capacity to implement the policy. In this light, the Deputy Minister of Manpower Youth and Employment tasked the department of social welfare to draft a suitable policy. According to Zahariadis"ideas and solutions that combine all three elements-national mood, pressure groups, and legislative turnover- tend to get the attention of policy makers" (2014, p. 34). However, legislative or administrative turnover was sufficient to catch the attention of policymakers to effect policy change by implementing LEAP.

\subsection{Policy Window and Policy Entrepreneur in the Case of LEAP}

The productive nature of a policy window largely depends of the policy entrepreneur because they oftentimes exploit policy windows to their advantage which ultimately results in policy change. There were pockets of resistance mainly from the minority in Parliament which created a window of opportunity that stimulated discussions on different policy options. The National Development Planning Commission also proposed that LEAP should mainly be a conditional cash transfer. However, the Chairman of the Commission Mr. J.H Mensah was opposed to the ideas and argued that LEAP bore semblance of a 'handout' and was not a sustainable option considering the fact that the economy of Ghana was not powerful (Grebe, 2014). The government ignored some of the concerns and pushed for the adoption of LEAP. Not only was LEAP met with resistance from NDPC, minority members of parliament accused the government of attempting to waste national resources. So, they vehemently opposed LEAP arguing, on economic grounds, that resources were difficult to mobilize and therefore, government needed to exercise fiscal prudence by focusing on aspects of the economy that will yield economic growth (Debrah, 2013). They also proposed that 
government should concern itself with policies that will create jobs for the youth and increase economic growth. With an assumption of what the minority MPs thought would earn them public sympathy and support, rather stirred public backlash and intensified the call for immediate government intervention. Some sections of the public chastised and tagged the minority MPs as insensitive to the plight of poor and vulnerable people. In the end, the original policy document of LEAP was massively endorsed in parliament, partly because the ruling government controlled the majority in the house.

Former President J. A. Kufuor is the policy entrepreneur whose relentless determination brought about policy change, hence, the implementation of LEAP. His drive was supported by the expertise and experiences of the Deputy Minister for Manpower Youth and Employment (Hon. Frema Osei-Opare), and the technocratic influence of the planning bureaucrats of the National Development Planning Commission. In fact, they worked together and their efforts were coordinated in a single direction to ensure that LEAP was accepted as a good policy. It is worth noting that with the enormous political power and influence of the president was the most important determinant in the process because, by virtue of the executive powers vested in him by the Constitution of the Republic of Ghana, he could single handedly shepherd the policy through parliamentary approval without any institutional constraints or meaningful support from the other two entrepreneurs. Grebe (2014) made the case that a former special advisor and later Deputy Minister of Finance, Dr. Anthony Akoto Osei said "it appears that social security and wage reform formed an important part of President Kufuor's policy agenda from the start of his term" (Grebe, 2014, p. 11). President Kufuor was encouraged to implement a social policy when he visit his colleague president of Brazil-President Lulla-in 2007 and, upon his return to Ghana, instructed the majority leader to expedite the process (MMYE, 2007). In March, 2008 LEAP was officially launched.

\section{Conclusion}

This paper argues that the policy entrepreneurial role of President Kufuor was critically important in bringing about policy change. That is to say, even though poverty was a glaring problem in Ghana, it took an individual commitment from Kufuor to ensure that a policy was crafted to appropriately address the plight of the poorest and vulnerable people. One can plausibly argue that LEAP was implemented in 2008 by the incumbent NPP government as a strategy to bolster its chances of winning the December polls within the same year. This is because most governments in developing countries often take advantage of, and abuse their incumbency by initiating certain rapid developmental projects that will remain fresh on the minds of the electorates going into elections. However, it is not the focus of analysis in this paper. Having said that, this paper further reaffirms the assertion made by Zahariadis (2014) that, the three streams are independent but they have to be active and converge at a critical point to open a policy window, through which policy change can be initiated. As noted in the period between 1992 and 2000, the policy and the politics streams were largely inactive and inevitably, the three streams could not be coupled. Finally, the broader implication of using MSA to explain LEAP is that even though Kingdon's multiple streams approach was designed and used to explain policy change in the US and probably the western world, the 
paper has demonstrated that it can be successfully applied or used to explain policy change in developing countries. By doing so it broadens the scope, validity and applicability of the theory.

\section{Acknowledgement}

I wish to sincerely express my profound gratitude to Professor Tim Heinmiller of the Department of Political Science at Brock University for his guidance and inputs on the first draft of this paper. My kind gratitude also goes to my brothers, Dr. Iddisah Sulemana and Mr. Yakubu Sakpawura for the immeasurable support.

\section{References}

Abebrese, J. (2011). Social Protection in Ghana: An overview of existing programmes and their prospects and challenges. Friedrich Ebert Stifting.

Adedeji, J. L. (2001). The legacy of JJ Rawlings in Ghanaian politics, 1979-2000. African Studies Quarterly, 5(2), 1-27.

Amazu, C., Jones, N., \& Pereznieti, P. (2010). Gendered risks, Poverty and Vulnerability in Ghana: To what extent is the Livelihood Empowerment Against Poverty cash transfer programme making a difference? Overseas Development Institute

Barrientos, A. (2013). The Rise of Social Assistance in Brazil. Development and Change 44(4), 887-910. https://doi.org/10.1111/dech.12043

Barrientos, A., \& Lloyd, S. P. (2002). Older and poorer? Ageing and poverty in the South. Journal of International Development, 14, 1129-1131. https://doi.org/10.1002/jid.954

Barrientos, A., Gorman, M., \& Heslop, A. (2003). Old Age Poverty in Developing Countries: Contributions and Dependence in Later Life. World Development, 31(3), 555-570. https://doi.org/10.1016/S0305-750X(02)00211-5

Bawelle, E. (2016). Livelihood Empowerment Against Poverty in Ghana: The Case study of Wa District. International Journal of Social Science Research, 4(2), 24-43. https://doi.org/10.5296/ijssr.v4i2.9415

Callister, L. C. (2013). Bolsa Familia: Reaching Brazil's Poorest of the Poor .Global Health and Nursing. September/October 2013.

Dako, G. M., \& Oduro, R. (2013). The Effects of Household size on Cash transfer Utilization for Orphans and Vulnerable Children in Rural Ghana. Academic Journal of Interdisciplinary Studies, 2(1), 239-251.

Debrah, E. (2009). The Economy and Regime Change in Ghana, 1992-2004. Ghana Social Science Journal, 5(1) \& 6(2), 84-113.

Debrah, E. (2013). Alleviating Poverty in Ghana: The case of Livelihood Empowerment Against Poverty. Africa Today, 59(4), 40-67. https://doi.org/10.2979/africatoday.59.4.41

Gerring, J. (2004).What Is a Case Study and What Is It Good For?. American Political 
Science Review, 98(2), 341-54. https://doi.org/10.1017/S0003055404001182

GSS. (2007). Ghana Living Standards Survey Round 5 (GLSS5): Poverty profile in Ghana (2005-2006). Accra, Ghana Statistical Service.

Government of Ghana. (2004). Poverty Reduction Strategy Review Paper. Accra.

Grebe, E. (2014). Donor agenda-setting, bureaucratic advocacy and cash transfers in Uganda (2002-2013) CSSR Working Paper No. 352. Cape Town: Centre for Social Science Research, University of Cape Town.

Grebe, E. (2015). The Politics of Social Protection in Competitive African Democracy: Explaining Social Protection policy in Ghana (2000-2014). Centre for Social Science Research, CSSR Working paper, No. 361 (August 2015).

Hall, A. (2006). From Fome Zero to Bolsa Familia: Social Policies and Poverty Alleviation under Lula. Journal of Latin American Studies, 38(4), 689-709. https://doi.org/10.1017/S0022216X0600157X

Handa, S., Park, M., Darko, R. O., Osei, A. I., Davis, B., \& Daidone, S. (2013). Livelihood empowerment against poverty program impact evaluation. Carolina Population Center, Chapel Hill, NC: University of North Carolina.

Ibrahim, M., \& Yeboah, T. (2013). Combating Poverty towards actualizing the Millennium Development Goals and beyond: Do Cash transfer Programme add up to the agenda? Journal of Economics and Social science Studies, 2(2), 101-132.

Ikiara, G. K. (2009). Political Economy of Cash Transfers In Kenya. A Report prepared for the Overseas Development Institute. August 2009. University of Nairobi.

ISEER. (1993). The State of the Ghanaian Economy, 1992, Accra: University of Ghana.

Kingdon, J. W. (1995). Agendas, Alternatives, and Public Policies. 2nd ed. New York: HarperCollins.

Kusi, A. O., Church, J., Conteh, C., \& Heinmiller, B. T. (2015). Resistance and change: a multiple streams approach to understanding health policy making in Ghana. Journal of health politics, policy and law, 40(1), 195-219. https://doi.org/10.1215/03616878-2854711

Lloyd, S. P. (2000). Population ageing in developed and developing regions: implications for health policy. Social Science \& $\quad$ Medicine, 51(6), 887-895. https://doi.org/10.1016/S0277-9536(00)00068-X

MMYE. (2007). The National Social Protection Strategy (NSPS). Accra: Ministry of Manpower, Youth and Employment.

Osei, R. D. (2011). Reducing Poverty through a Social Grant Programme: The Case of Ghana. Institute of Social Science and Economic Research, Accra.

Rabinovich, L., \& Diepeveen, S. (2015).The Design of Conditional Cash Transfers: Experiences from Argentina's Universal Child Allowance. Development Policy Review, 33(5), 
637-652. https://doi.org/10.1111/dpr.12127

Republic of Kenya. (2009). National Social Protection Policy, Draft 3, Ministry of Gender, Children and Social Development, Nairobi, May 2009(a).

Roelen, K., Chettri, K. H., \& Delap, E. (2015). Little Cash to large Households: Cash Cash Transfers and Children's Care in disadvantaged families in Ghana. International Social Security Review, 68(5), 63-83. https://doi.org/10.1111/issr.12064

Schubert, B. (2005). The pilot social cash transfer scheme Kalomo district-Zambia.

Skovdal, M., Mushati, P., Robertson, L., Munyati, S., Sherr, L., Nyamukapa, C., \& Gregson, S. (2013). Social acceptability and perceived impact of a community-led cash transfer programme in Zimbabwe. BMC Public Health, 13(1), 342. https://doi.org/10.1186/1471-2458-13-342

Soares, S. (2012). Bolsa Família, its design, its impacts and possibilities for the future Working paper no. 89. International Policy Centre for Inclusive Growth, UNDP.

Stephen, T. R. (2002). Assisting the poor with cash: Design and Implementation of Social Transfer Programs. Social Protection Discussion Paper Series, No. 0223

World Bank. (1995). Ghana: Poverty Past, Present and Future. Washington, D.C: World Bank.

Zahariadis, N. (2014). Ambiguity and multiple streams. Theories of the Policy Process, 3, 25-59.

\section{Copyright Disclaimer}

Copyright for this article is retained by the author(s), with first publication rights granted to the journal.

This is an open-access article distributed under the terms and conditions of the Creative Commons Attribution license (http://creativecommons.org/licenses/by/4.0/). 